\title{
CORRELATION BETWEEN YIELD COMPONENTS IN F6 SOYBEAN PROGENIES DERIVED FROM SEVEN BIPARENTAL CROSSES
}

\author{
CORRELAÇÃO ENTRE CARACTERES EM PROGÊNIES F6 DE SOJA \\ PROVENIENTES DE SETE CRUZAMENTOS BIPARENTAIS
}

\section{Larissa Barbosa de SOUSA ${ }^{1}$; Osvaldo Toshiyuki HAMAWAKI ${ }^{1}$; Célio Dias SANTOS JÚNIOR $^{2}$; Valécia Martins de OLIVEIRA ${ }^{3}$; Ana Paula Oliveira NOGUEIRA ${ }^{4}$; Fernanda de Melo MUNDIM ${ }^{5}$; Raphael Lemes HAMAWAKI ${ }^{6}$; Cristiane Divina Lemes HAMAWAKI ${ }^{7}$}

1. Professores do Instituto de Ciências Agrárias - ICIAG da Universidade Federal de Uberlândia - UFU, Uberlândia, MG, Brasil. larissa@iciag.ufu.br e hamawaki@umuarama.ufu.br; 2. Mestrando em Biologia Celular, Universidade Federal de São Carlos, São Carlos-SP, Brasil.celio.diasjunior@gmail.com; 3. Mestre em Agronomia, Universidade Federal de Uberlândia, Uberlândia-MG. valeciamo@yahoo.com.br; 4. Professora do Instituto de Genética e Bioquímica, Universidade Federal de Uberlândia, Uberlândia-MG. anap@ingeb.ufu.br. 5. Mestranda em agronomia, Universidade Federal de Uberlândia-MG. ff_mundim@ hotmail.com; 6. Mestre em fitotecnia - Melhoramento de plantas, Universidade Federal de Uberlândia, Uberlândia-MG. raphael.hamawaki@ yahoo.com.br; 7. Professora da UNIPAC, Araguari-MG. crishamawaki@yahoo.com.br.

\begin{abstract}
Breeding programs strive to obtain cultivars with superior traits. The association between these characters, such as those estimated by correlation coeficients, are important to the breeding selection process. In this study we analyzed phenotypic and genotypic correlations between yield and other agronomic traits in soybean progenies derived from various crosses to support breeding line selection in the soybean breading program of the Federal University of Uberlandia (UFU). The experiment was carried out in the 2011/2012 growing season at the Capim Branco research station in Uberlandia, Minas Gerais, Brazil. Seventy-one soybean lines were evaluated using a randomized complete block design with three replications. In these plots plants were evaluated for the number of pods, grain yield per plant, number of days for flowering, plant height at flowering, number of days for maturity, plant height at maturity, height of the first pod insertion, number of grains per pod and grain yield per plant. The estimates for genotypic correlations were equal or greater than those for the phenotypic correlations for all the evaluated traits. This suggests a small effect of environmental factors on the trait expression. An exception of this behavior was the correlation between plant height at flowering and plant height at maturity. In this case, although the signs for the genotypic and phenotypic correlations were the same, the value for the last was greater than that for the former. The late flowering and late-maturing plants were taller. Also, selecting plants for higher number of pods ultimately contributed for the selection of plants with higher grain yield. The selection of late-flowering and late-maturing plants have yielded taller plantsin the same way that the selection for a higher pod number could promote the selection and improvement of grains yield trait.
\end{abstract}

KEYWORDS: Indirect selection. Breeding. Coefficient of determination.

\section{INTRODUCTION}

An important plant breeding aspect is the decision about which characters should be used in indirect selection. Those of easy determination are preferable. since this aspect can make the difference to studyfactors correctly (NASCIMENTO-FILHO; ATROCH; REGAZZI, 2011).

The study of characters association is essential for crop improvement. Mainly for those with low heritability or difficulty to measure and identify (CRUZ; REGAZZI; CARNEIRO, 2012). The ultimate goal of every plant breeding program is to obtain lines capable of exceeding the performance of current cultivars available in the market. In order to add new desired characteristics the new line must have other advantageous phenotypic characters. In addition to high-yielding, characters which reduce costs, improve resistance to pests and diseases and use more efficiently water and nutrients are strongly pursued (RAMALHO et al., 2012).

The importance of characters correlation in genetic studies is based on the possibility to assess quantitative changes in a character which interferes in another one. Currently, the long-term selection goal is to maintain the expression of a main character and at the same time keep or improve the expression of others (LOPES et al., 2002). Thus, the knowledge about the association between characters have been extremely relevant to crop improvement since it provides a useful information for breeders who will perform the selection process (NOGUEIRA et al., 2012).

When the goal is to improve characters with low heritability it is possible to use the indirect 
selection. This technique makes use of a trait with high heritability and easy evaluation and, due to its correlation with a low heritability trait, is used for the selection process (ALMEIDA; PELÚZIO; AFERRI, 2010).

The correlation coeficient is a statistical estimate which measures how linear is the association between two variables; still, it can be also defined as the joint variation measurement which can be positive or negative (RAMALHO et al., 2012). Based on correlation estimates it is possible to use the indirect selection. This will provide faster genetic gain when compared with the direct selection (CRUZ; REGAZZI; CARNEIRO, 2012).

Correlation coefficients have no units and their absolute values do not exceed the unit. The closer these estimates are to -1 or +1 the stronger will be the association between the two variables. When the correlation coefficient equals to zero it means there is no linear association between the two variables. However, this does not imply no association between the two variables, in fact the variables can still have associations other the linear (NOGUEIRA, 2011). A negative correlation means the characters are inversely correlated; meaning they vary in opposite directions. On the other hand, a positive correlation means the characters vary in the same direction.

Although two characters can be correlated due to a variety of factors such as phenotypic, genotypic or environmental, the phenotypic and the genotypic ones are those of major interest to the genetic improvement since they comprise those of inheritable nature (NOGUEIRA et al., 2012).

The correlation estimates are determined by the genetic base of the population where the characters are evaluated. They may vary from positive to negative estimates. This provides an indication of how strong can be the influence of a character in another (HEIKO, 2001).

In soybean, studies involving genotypic, phenotypic and environmental correlations have evaluated characters from flowering to maturity; emphasizing those associated to yield and its components (e,g, plant height at flowering and maturity, number of days to flowering and maturity, etc) (ROMANATO, 2013; ALMEIDA; PELÚZIO; AFERRI, 2010, NOGUEIRA et al., 2012; POPOVIC et al., 2012; PERINI et al., 2012; BÁRBARO et al., 2007; PELÚZIO et al., 1997). In The objective of this study was to evaluate the phenotypic and genotypic correlations among agronomic characters of soybean lineages derived from different crosses. These estimates aim to support the selection process applied by the Soybean Breeding Program of Federal University of Uberlandia.

\section{MATERIAL AND METHODS}

The experiment was carried out at the research station of the Capim Branco farm (18 ${ }^{\circ} 52^{\prime} \mathrm{S}$; $48^{\circ} 20^{\prime} \mathrm{W}$ and $805 \mathrm{~m}$ of altitude) of the Federal University of Uberlandia, in Uberlandia, Minas Gerais state, during 2011/2012 growing season.

The soil in the research station is characterized by a dystrophic dark red oxisol. Before the planting a soil test was performed in order to meet the nutrient demand by the crop. Soil preparation was done using a conventional tillage.

Seventy one (71) soybean lines derived from seven biparental crosses were evaluated. The progenies were obtained using the genealogic method on which individual plants were selected in the F2 generation. In the F3 generation each selected plant was planted in a line and the selection was performed between lines and within each line. In the last generation seeds from each selected individual plant were planted again in a line and a new selection was performed between and within lines. This same procedure was repeated until the F6 generation.

The experimental design was the randomized complete block (RCB) with three replications. The plots consisted of two rows of soybean plants $4 \mathrm{~m}$ long and $0.5 \mathrm{~m}$ apart. Harvested were 3 meters of each row. The seed rate was 20 seeds per meter planted $3 \mathrm{~cm}$ depth. At the V1 stage of development (FEHR; CAVINESS, 1977) plants were thinned to 15 plants per meter aiming a population of 300.000 plants per hectare. The seed treatment was performed using $200 \mathrm{~mL}$ of both the Fludioxonil Maxim $^{\mathrm{TM}}$ XL) and the Tiametoxam (Cruiser $^{\mathrm{TM}} 350 \mathrm{FS}$ ) for each $100 \mathrm{~kg}$ of seeds. Additionally the seed inoculation was performed using the Bradyrhizobium japonicum. The weed control was performed using both pre and postemergent herbicides. Hand weeding was also performed when necessary. Disease and pest control were carried out following the recommendations suggested by the EMBRAPA (2011). The evaluated agronomic traits were those most relevant for yield determination in the soybean crop. These characters were assessed using visual evaluations according to the stages of development for the crop proposed by Fehr \& Caviness (1977). These are as follows:

a) Plant height at flowering (PHF): distance (cm) from the soil surface to the apex of the main stem of five random plants; 
b) Plant height at maturity (PHM): distance (cm) from soil to the apex of the main stem of five random plants at the R8 stage when $95 \%$ of the pods in a plot had reached the mature pod color;

c) Number of days for flowering (NDF): the number of days from emergence to flowering when approximately $50 \%$ of plants in a plot had at least one flower (R1).

d) Number of days for maturity (NDM): number of days from emergence to maturity, when $95 \%$ of the pods in a plot had reached the mature pod color (R8).

e) Height of the first pod (HFP): distance (cm) from the soil surface to the first pod on the main stem with the five randomly selected plants at the same stage (R8).

f) Total number of pods: number of pods of five randomly selected plants per plot. The average of the five plants was considered as the final value.

g) Number of seeds per pod: the number of seeds of five randomly selected plants was obtained and divided by the number of pods. This value was obtained for each plant and an average of the five plants was considered as the final value; h) Grain yield per plant (GY): after harvest pods were threshed and seeds weighed from five randomly selected plants.

Estimates for the phenotypic and genotypic coeficient of correlation between characters were obtained as proposed by Ramalho et al. (2012).

The broad-sense heritability $\left(\mathrm{h}^{2}\right)$ for each trait was estimated based on the analysis of variance (ANOVA) method.

The significance of the phenotypic correlation was tested usint the $\mathrm{t}$ test with $\mathrm{n}-2$ degrees of freedom where $\mathrm{n}$ is the number of assessed genotypes, whereas the significance of genotypic correlation was tested using the bootstrap method with simulation of 5,000 samples. All the statistical analysis were performed using the Genes software (CRUZ, 2013).

\section{RESULTS AND DISCUSSION}

In Table 1 are presented the summary of ANOVA data to the evaluated agronomic traits. The significant effects for lines can be verified in the lines row. This indicates the existence of genetic variability.

Table 1. ANOVA summary to the eight evaluated agronomic traits in 71 soybean lines grown in UberlandiaMG.

\begin{tabular}{ccccccccc}
\hline Source of Variation & \multicolumn{7}{c}{ Mean of Square } \\
\cline { 2 - 9 } & TNP & GY & ND & PHF & NDM & PHM & HFP & NSP \\
& & & F & & & & & \\
\hline Block & 211.37 & 69.89 & 12.97 & 319.22 & 168.88 & 237.83 & 30.18 & 0.02 \\
Lines & $463.94^{* *}$ & $37.25^{* *}$ & $9.83^{*}$ & $73.00^{* *}$ & $81.15^{* *}$ & $206.26^{* *}$ & $10.61^{* *}$ & $0.18^{* *}$ \\
Error & 140.56 & 10.71 & 5.66 & 37.72 & 21.97 & 43.26 & 4.66 & 0.02 \\
CV $(\%)$ & 19.33 & 12.97 & 5.04 & 14.71 & 3.74 & 11.02 & 20.96 & 5.51 \\
$\mathrm{~h}^{2}$ & 69.70 & 71.24 & 42.43 & 48.32 & 72.93 & 79.03 & 56.03 & 89.92 \\
\hline
\end{tabular}

**: significant at 0.01 level by Fisher $\mathrm{F}$ test. $\mathrm{CV}(\%)$ :coefficient of variation. $\mathrm{h}^{2}$ : broad-sense heritability coefficient. TNP: total number of pods, GY: grain yield per plant (kg.plant ${ }^{-1}$ ), NDF: number of days for flowering, PHF: Plant height at flowering, NDM: Number of days for maturity, PHM: Plant height at maturity, HFP: Height of first pod and NSP: number of seeds per pod.

The coefficient of variation $(\mathrm{CV})$ for the eight characters varied from $3.74 \%$ to $20.96 \%$, respectively. For the number of days for maturity (NDM) and the height of first pod (HFP). The estimates for the CV were considered of low to medium levels (PIMENTEL, 1985) which evidenced the control of environmental effect. Regarding the higher values of the $\mathrm{CV}$ these are due to the quantitative and polygenic nature of these traits according to the values observed in other studies with soybean (ESPINDOLA et al., 2011, PERINI JÚNIOR et al., 2012; NOGUEIRA et al., 2012; BÁRBARO et al., 2007; HEIKO, 2001). It is worth to note that the minimum value of $\mathrm{CV}$ came from number of days for maturity $(2.70 \%)$ and the greater from grain yield per plant $(37.71 \%)$. This last estimate is more than twice of that obtained in this study for the same character.

According to Carvalho et al. (2003), the upper limit for the coefficient of variation for soybean is $12 \%$ for plant height and $16 \%$ for grain yield per plant. In this study, for these same traits, the observed estimates for the $\mathrm{CV}$ were close to the suggested limits. The only exceptions were the number of days for flowering (NDF) and the number of days for maturity (NDM) whose CVs were $5.04 \%$ and $3.74 \%$, respectively. These estimates were lower than expected.

Estimates of broad-sense heritability $\left(\mathrm{h}^{2}\right)$ ranged from $42.43 \%$ (NDF) to $89.92 \%$ (NSP). The 
$\mathrm{h}^{2}$ provides the proportion of the genetic variance present in the total phenotypic variance. Therefore, it measures the confidence in using the phenotypic value to estimate the genotypic one (RAMALHO et al., 2012). Nevertheless, the character NDF was the one most affected by the environment and therefore the selection of genotypes for this trait is not reliable.

The estimates for the phenotypic and genotypic correlation coefficientsfor all pair-wise characters are presented in Table 2. To interpret the results three aspects should be taken into consideration, and those are the amplitude, direction and significance. When the correlation coefficient has a positive sign this means both increase together, whereas a negative correlation coefficient indicates one variable increase while the other decreases (NOGUEIRA et al., 2012).

Table 2. Phenotypic $\left(r_{f}\right)$ and genotypic $\left(r_{g}\right)$ correlation coefficients for eight agronomic traits evaluated in 71 soybean lines grown in Uberlandia-MG.

\begin{tabular}{|c|c|c|c|c|}
\hline & & & \multicolumn{2}{|c|}{ CORRELATIONS } \\
\hline \multicolumn{3}{|c|}{ CHARACTERS } & $\mathrm{r}_{\mathrm{f}}$ & $\mathrm{r}_{\mathrm{g}}$ \\
\hline NTV & $\mathrm{X}$ & GY & $0.5951 * *$ & $0.6699^{++}$ \\
\hline NTV & $X$ & NDF & $0.1599^{\mathrm{ns}}$ & 0.2718 \\
\hline NTV & $X$ & PHF & $-0.1087^{\mathrm{ns}}$ & -0.2544 \\
\hline NTV & $X$ & NDM & $-0.0809^{\mathrm{ns}}$ & -0.1818 \\
\hline NTV & $X$ & PHM & $-0.0290^{\mathrm{ns}}$ & -0.0721 \\
\hline NTV & $X$ & HFP & $-0.2295^{\mathrm{ns}}$ & -0.2998 \\
\hline NTV & $X$ & NSP & $-0.4491 * *$ & $-0.5648^{++}$ \\
\hline GY & $X$ & NDF & $0.1379^{\mathrm{ns}}$ & 0.2155 \\
\hline GY & $X$ & PHF & $-0.0806^{\mathrm{ns}}$ & -0.1808 \\
\hline GY & $X$ & NDM & $-0.081^{\mathrm{ns}}$ & -0.1319 \\
\hline GY & $X$ & PHM & $0.0585^{\mathrm{ns}}$ & 0.0878 \\
\hline GY & $X$ & HFP & $-0.1786^{\mathrm{ns}}$ & -0.2792 \\
\hline GY & $X$ & NSP & $-0.1145^{\mathrm{ns}}$ & $-0.1577^{+}$ \\
\hline NDF & $X$ & PHF & $0.5905^{* *}$ & $0.7520^{+}$ \\
\hline NDF & $X$ & NDM & $0.407 * *$ & $0.5627^{+}$ \\
\hline NDF & $X$ & PHM & $0.4678 * *$ & $0.8067^{++}$ \\
\hline NDF & $X$ & HFP & $0.4061 * *$ & $0.8383^{++}$ \\
\hline NDF & $X$ & NSP & $0.0409^{\mathrm{ns}}$ & 0.0340 \\
\hline $\mathrm{PHF}$ & $X$ & NDM & $0.0033^{\mathrm{ns}}$ & -0.0898 \\
\hline $\mathrm{PHF}$ & $X$ & PHM & $0.3056^{* *}$ & 0.2634 \\
\hline $\mathrm{PHF}$ & $X$ & HFP & $0.5348 * *$ & $0.8383^{++}$ \\
\hline $\mathrm{PHF}$ & $X$ & NSP & $0.1063^{\mathrm{ns}}$ & 0.1260 \\
\hline NDM & $X$ & PHM & $0.2689 *$ & $0.3227^{+}$ \\
\hline NDM & $X$ & HFP & $-0.0335^{\mathrm{ns}}$ & -0.1283 \\
\hline NDM & $X$ & NSP & $-0.0401^{\mathrm{ns}}$ & $-0.0497^{+}$ \\
\hline PHM & $X$ & HFP & $0.373 * *$ & 0.3747 \\
\hline PHM & $X$ & NSP & $0.0225^{\mathrm{ns}}$ & 0.0301 \\
\hline HFP & $X$ & NSP & $0.2132^{\mathrm{ns}}$ & 0.3294 \\
\hline
\end{tabular}

**, *: significant at the 0.01 and 0.05 levels by the Student's t test, respectively; ${ }^{\text {ns: }}$ non-significant. ${ }^{++},{ }^{+}:$significant at 0.01 and 0.05 levels by the bootstrap method using 5,000 bootstrap simulations. NVT: total number of pods, GY: grains yield per plant $\left(\mathrm{g}\right.$.plant $\left.{ }^{-1}\right)$, NDF: number of days to flowering, PHF: plant height at flowering, NDM: number of days to maturity, PHM: plant height at maturity, HFP: height of first pod and NSP: number of grains per pod.

The phenotypic correlation is evaluated in the breeding process and it is constituted by genetic and environmental factors (FALCONER, MACKAY, 1996). For all the traits, except for PHF and PHM, the genotypic correlations were higher than the phenotypic ones. They also had the same direction (i.e. positive sign) which suggests a small environmental effect on traits expression (ALMEIDA; PELUZIO; AFERRI, 2010). This same trend was observed in other studies with soybean characters correlation (CARVALHO et al., 2002; LOPES et al., 2002; PELÚZIO et al., 2005; GONÇALVES et al., 2005, ARSHAD, ALI, GHAFOOR, 2006; ALMEIDA, PELUZIO, 
AFERRI, 2010; SHOWKAT; TYAGI, 2010, ROMANATO, 2013).

Genotypic correlations higher than phenotypic ones is a very promising result for breeding programs which main goal is to perform the indirect selection. However a high correlation between the two characters does not guarantee by itself a successful selection of one character through the other since it should also be considered the character heritability (ROMANATO, 2013).

The significant observed phenotypic and genotypic correlations observed between NTV and GY (0.5951), NDF and PHF (0.5905), and between PHF and HFP (0.5348), despite to be close have a concordant behavior. Therefore, the direct selection for greater number of pods can improve the selection for plants with higher grain yield; since the number of pods is one of the yield components (PERINI JÚNIOR et al., 2012). These results are in accordance with those obtained by Nogueira et al. (2012) which evaluated the phenotypic and genotypic correlation between agronomic traits in 90 soybean genotypes and obtained a phenotypic correlation of 0.767 for the same evaluated traits. According to the results the greater the number of days for flowering the taller will be the plants at the same developmental stage. Plants which delay for reaching the reproductive stage also acumulate more dry matter since it continues to grow. Thus, the selection for late-maturing plants yield taller plants. This result was similar to that found by Almeida et al. (2010) which evaluated the correlation of agronomic traits in 12 soybean genotypes.

The character NDF also showed significant genotypic and phenotypic correlation with NDM meaning that the selection of plants which delay for reaching the reproductive stage yield late-maturing plants. A similar result was observed by Romanato (2013) who evaluates the phenotypic and genotypic correlations between nine agronomic traits in 27 soybean genotypes. A significant genotypic and phenotypic correlation of 0.61 and 0.64 , respectively was obtained. Also Salimi and Moradi (2012) found correlations for the same evaluated characters when studying the effect of correlation, regression and path analysis in soybean genotypes under normal and excessive moisture.

The plant height at flowering showed significant positive phenotypic correlation with plant height at maturity and with the height of first pod. This implies the selection of higher plants in the reproductive stage can result in taller plants at maturity and in an upper height of first pod; this result agrees with taht obtained by Pelúzio et al. (2005) and Nogueira et al. (2012).
The positive correlations occurred possibly due to the occurrence of pleiotropism or gene linkage which is the disequilibrium between pairs of characters and which favors the simultaneous selection of two or more characters through the selection of only one of these (FALCONER, MACKAY, 1996). Nevertheless, due to this relationship, the selection of a character can cause the selection of an undesirable one (ALMEIDA; PELÚZIO; AFERRI 2010).

The total number of pods presented a negative correlation with the number of grains per pod. In other words, the selection of plants with higher number of pods will result in plants with fewer number of grains per pod. This connection can be explained by the translocation of photosynthates to produce higher number of pods which implies the portion of these which will be translocated to the grains will be smaller.

Pandini et al. (2002) evaluated correlations between traits in soybean and reported the character number of pods per plant have potential for indirect selection of more productive genotypes. According to these authors, the characters of agronomic value may be correlated in different magnitudes. This implies the selection of a character can yield unexpected results; these can be desirable or not.

The study of correlations between characters related to grain yield is of foremost importance for breeding programs. The main reason for the use of these estimates is that it makes easier the breeder's task of selection of favorable genotypes (PELUZIO et al., 1998).

The most part of the characters did not show significant correlations with grain yield and also presented low values. However, this does not imply no correlation between these characters since they can still have a non-linear correlation or yet they can have another type of association.

\section{CONCLUSIONS}

Genotypic correlation coefficients between agronomic traits in soybean presented hererevelead to be higher as their phenotypic counterparts, as a synergistic association. This implies the phenotypic expression is reduced in front of environment influence, not under genetic conditions.

The selection of late-flowering and latematuring plants yielded taller plants when performed at the same stage. Additionally, the selection for higher pod number can lead towards higher grain yield. 
RESUMO: O objetivo dos programas de melhoramento genético de qualquer cultura é a obtenção de cultivares que superem com vantagens as pré-existentes. Desse modo, o conhecimento das relações entre caracteres, tais como estimadas pelas correlações, tem apresentado grande importância para o sucesso dos processos de seleção no melhoramento. Os objetivos deste estudo foram avaliar as correlações fenotípicas e genotípicas entre caracteres agronômicos de linhagens de soja oriundas de diferentes cruzamentos, visando fornecer subsídios para fins de seleção a ser adotado no programa de melhoramento genético de soja da Universidade Federal de Uberlândia. O experimento foi conduzido em uma área experimental localizada na Fazenda Capim Branco, pertencente à Universidade Federal de Uberlândia, no município de Uberlândia, Minas Gerais, na safra 2011/2012. Foram avaliados 71 linhagens de soja em delineamento de blocos completos casualisados com três repetições. Avaliaram-se os caracteres: número total de vagens, produção de grãos por planta, número de dias para o florescimento, altura da planta no florescimento, número de dias para maturidade, altura da planta na maturidade, altura de inserção de primeira vagem, número de grãos por vagem e produção de grãos por planta. Para todos os caracteres, com exceção da correlação entre altura da planta no florescimento e maturidade em que a apesar de apresentarem mesma direção, a magnitude da correlação fenotípica superou a correlação genotípica, as correlações genotípicas foram superiores as fenotípicas e de igual sinal, indicando menor influência do ambiente na expressão dos caracteres. A seleção de plantas mais tardias no florescimento e maturidade, resulta em plantas mais altas nesses estádios de desenvolvimento, bem como a seleção de plantas com maior número de vagens favorece a seleção e melhoramento para o caractere produção de grãos por planta.

PALAVRAS-CHAVE: Seleção indireta. Melhoramento. Coeficiente de determinação.

\title{
REFERENCES
}

ALMEIDA, R. P.; PELÚZIO, J. M.; AFERRI, F. S. Correlações fenotípicas, genotípicas e ambientais em soja cultivada sob condições várzea irrigada, sul do Tocantins. Bioscience Journal, Uberlândia, v. 26, n. 1, p. 9599, 2010.

ARSHAD, M.; ALI N.; GHAFOOR A. B. Character correlation and path coefficient in soybean Glycine max (L.) Merrill. Pakistan Journal Botany, Karachi, v. 38, n. 1, p. 121-130, 2006.

BÁRBARO, I. M.; et al. Variabilidade e correlações entre produtividade de grãos e caracteres agronômicos de soja com aptidão para cultivo em áreas para reforma de canavial. Científica, Jaboticabal, v. 35, n. 2, p. 136 145, 2007.

CARVALHO, C. G. P.; et al. Correlações e análise de trilha em linhagens de soja semeadas em diferentes épocas. Pesquisa Agropecuária Brasileira, Brasília, v. 37, n. 3, p. 311-320, 2002.

http://dx.doi.org/10.1590/S0100-204X2002000300012

CARVALHO, C. G. P.; et al. Proposta de classificação dos coeficientes de variação em relação à produtividade e altura da planta de soja. Pesquisa Agropecuária Brasileira, Brasília, v. 38, n. 2, p. 187-193, 2003. http://dx.doi.org/10.1590/S0100-204X2003000200004

\author{
CARVALHO, F. I. F.; LORENCETTI, C.; BENIN, G. Estimativas e Implicações da correlação no \\ melhoramento vegetal. Pelotas: UFPel, p 142. 2004.
}

CRUZ, C. D.; REGAZZI, A. J.; CARNEIRO, P. C. S. Modelos biométricos aplicados ao melhoramento genético. Viçosa, MG: UFV, 2012. v. 1, 514 p.

CRUZ, C. D. GENES - a software package for analysis in experimental statistics and quantitative genetics. Acta Scientiarum. Agronomy, Maringá, v. 35, n.3, p. 271-276, 2013.

EMPRESA BRASILEIRA DE PESQUISA AGROPECUÁRIA. Tecnologias de produção de soja: região central do Brasil 2012 e 2013. - Londrina: Embrapa Soja, 2011. 261 p. 
ESPINDOLA, S. M. C. G.; et al. Avaliação da performance produtiva e agronômica de genótipos de soja para a região de Jaboticabal, SP. FAZU em Revista, Uberaba, n. 8, p. 20-24, 2011.

FALCONER, D. S.; MACKAY, T. F. C. Introduction to quantitative genetics, 4.ed. Longmans Green, Harlow, Essex, UK, 1996, 464p.

FEHR, W. R.; CAVINESS, C. E. Stages of soybean development. Ames: Iowa State University. Special Report, 80, Iowa Cooperative Extensive Service, Iowa, 12 p, 1977.

GONÇALVES, E. C. P.; et al. Estimativas de correlações fenotípicas em populações em populações de soja em plantio de safrinha. Revista Pesquisa \& Tecnologia, São Paulo, v. 2, n. 2, 2005.

HEIKO, R. Estimativas de parâmetros genéticos e fenotípicos de uma população de soja avaliada em quatro anos. 2001. 80f. Dissertação (Mestrado em Agronomia: Genética e Melhoramento de Plantas) - Escola Superior de Agricultura "Luiz Queiroz”, Universidade de São Paulo. Piracicaba, 2001.

LOPES, A. C. A.; et al. Variabilidade e correlações entre caracteres em cruzamentos de soja Scientia Agricola, Piracicaba, v. 59 n. 2 p. 341-348, 2002.

NASCIMENTO-FILHO, F. J.; ATROCH, A. L.; REGAZZI, A. J. Avaliação de características de mudas de clones de guaranazeiro utilizando análise de fatores. Revista Ciências Agrárias, Belém, v. 54, n. 2, p. $107-$ 112, 2011. http://dx.doi.org/10.4322/rca.2012.002

NOGUEIRA, A. P. O.; et al. Análise de trilha e correlações entre caracteres em soja cultivada em duas épocas de semeadura. Bioscience Journal, Uberlândia, v. 28, n. 6, p. 877-888, 2012.

NOGUEIRA, A. P. O. Correlações, análise de trilha e diversidade fenotípica e molecular em soja. Viçosa, 2011. 139f. Tese (Doutorado em genética e melhoramento de plantas) - Faculdade de Ciências agrárias, Universidade Federal de Viçosa, 2011.

PANDINI, F.; VELLO, N. A.; LOPES, A. C. A. Heterosis in soybeans for seed yield components and associated traits. Brazilian Archives of Biology and Technology, Curitiba, v. 45, n. 4, p. 401-412, 2002. http://dx.doi.org/10.1590/s1516-89132002000600001

PELÚZIO, J. M.; et al. Correlações entre caracteres de soja em Gurupi Tocantins. Revista Ceres, Viçosa, v. 52 p. 779-786 2005 .

PELUZIO, J. M.; et al. Correlações fenotípicas, genotípicas e ambiente entre alguns caracteres de soja, em Pedro Afonso, Tocantins. Revista Ceres, Viçosa, v. 45, p. 303-308, 1998.

PELÚZIO, J. M.; et al. Correlações entre caracteres agronômicos em cultivares de soja, em Gurupi-To. Revista Agricultura Tropical, Cuiabá, v. 3, n. 1, p. 15-24, 1997.

PERINI JÚNIOR, L.; et al. Componentes da produção em cultivares de soja com crescimento determinado e indeterminado. Semina - Ciências Agrárias, Londrina, v. 33, n. 1, p. 2531-2544, 2012.

PIMENTEL, G. F. Curso de estatística experimental. São Paulo: Esalq, 1985. 467p.

POPOVIC, V.; et al. Variability and correlations between soybean yield and quality components. Romanian agricultural research, Ălăraşi, v. 29, n. 29, 2012.

RAMALHO, M. A. P.; et al. Aplicações da genética quantitativa no melhoramento de plantas autógamas. Ed. Lavras: Ed. UFLA, Lavras, 2012, 522p. 
ROMANATO, F. N. Correlação, adaptabilidade e estabilidade de genótipos de soja. Uberlândia, 2013. 62. Dissertação (Mestrado em Agronomia - fitotecnia) - Instituto de Ciências Agrárias, Universidade Federal de Uberlândia, 2013.

SALIMI, S.; MORADI, S. Effect the Correlation, Regression and Path Analysis in Soybean Genotypes (Glycine max L.) under Moisture and normal condition. Journal of Agronomy and Plant Production. Tehran, v. 3, n. 10, p. 447-454, 2012.

SHOWKAT, M.; TYAGI, D. Correlation and path analysis of some quantitative traits in soybean (Glycine max L. Merrill). Research Journal of Agricultural Sciences, Timişoara, v. 1, p. 102-106, 2010. 